\title{
Scientific Production of Rectors of Peruvian Universities
}

\author{
Renzo Carranza-Esteban ${ }^{1}$, Josué Turpo-Chaparro²*, Ronald M. Hernández ${ }^{3}$, \\ Oscar Mamani-Benito ${ }^{4}$ and Abel Apaza-Romero ${ }^{5}$
}

' Grupo de Investigación Avances en Investigación Psicológica, Facultad de Ciencias de la Salud, Universidad San Ignacio de Loyola, Lima, Peru, ${ }^{2}$ Escuela de Posgrado Universidad Peruana Unión, Lima, Peru, ${ }^{3}$ Facultad de Humanidades, Universidad Católica Santo Toribio de Mogrovejo, Chiclayo, Peru, ${ }^{4}$ Universidad Señor de Sipan, Chiclayo, Peru, ${ }^{5}$ Facultad de Ciencias Humanas y Educación, Universidad Peruana Unión, Lima, Peru

The objective is to analyze the scientific production of the rectors of licensed Peruvian universities. The scientific production of the rectors was identified through the search of their publications registered in Scopus and Web of Science. It was reported that only $14.29 \%$ of Rectors have published articles and the average h-index in the databases is 3.62 and 1.14, respectively. It is concluded that the scientific production of the rectors is low, and it is important to establish policies that help the universities to have criteria in the election of the rector in relation to their scientific production.

Keywords: Peruvian scientific production, rectors, Peruvian universities, university research, Peruvian research

\section{OPEN ACCESS}

Edited by:

Gerardo Blanco,

Boston College, United States

Reviewed by:

Concepcion Naval,

University of Navarra, Spain

Laura Sara Agrati,

University of Bergamo, Italy

*Correspondence: Josué Turpo-Chaparro josuetc@upeu.edu.pe

Specialty section:

This article was submitted to

Higher Education,

a section of the journal

Frontiers in Education

Received: 30 September 2021

Accepted: 21 January 2022

Published: 07 March 2022

Citation:

Carranza-Esteban $R$

Turpo-Chaparro J, Hernández RM,

Mamani-Benito $O$ and

Apaza-Romero A (2022) Scientific

Production of Rectors of Peruvian

Universities. Front. Educ. 7:772887.

doi: 10.3389/feduc.2022.772887

\section{INTRODUCTION}

In recent years, there has been a discussion about the low Peruvian scientific production compared to other countries in the region (Hernández, 2019; Roman-Gonzalez et al., 2019). Even though some reports reveal that there has been improvement in some branches such as biomedical research (Glass et al., 2018), it is still pending to promote the exercise of research in other areas of health (Valle and Perales, 2016).

In this sense, the scientific literature shows some factors that could be influencing the low scientific production of a country; thus, some studies highlight the importance of economic investment, represented in the remuneration of research teachers, implementation of laboratories, subsidies for research projects, among other actions (Moquillaza-Alcántara, 2019). Also, highlight the fact of having qualified human resources to guide research from undergraduate. Regarding this fact, in Peru, it has been evidenced that only a small percentage of university teachers (ChachaimaMar et al., 2019), teachers with a doctorate degree (Mejia et al., 2018), advisors (Mamani-Benito et al., 2020; Mamani-Benito and Farfán-Solís, 2020) and thesis jurors (Mamani-Benito et al., 2019), demonstrate capacities to generate scientific production.

Changing the scenario but not the subject, it is necessary to also include university quality, which since 2014 has had significant improvements as a result of the licensing process of Peruvian universities in charge of the National Superintendency of Higher University Education (SUNEDU) (Mayta-Tristán et al., 2019), although of course, this process of change is still in its first phase. Finally, the issue of research management through the deans of the health faculties (ValenzuelaRodriguez et al., 2015; Aquino-Canchari, 2020) and the vice-rectors of research (Herrera-Añazco et al., 2017), which according to the results of some investigations do not show significant scientific production, that is, they seem not to be able to manage formative research; However, a study carried out in Turkey with Rectors from 197 universities highlights that those who graduated from foreign universities have better academic qualifications and more scientific publications than those Rectors who graduated from Turkish universities (Karadag, 2021). 
TABLE 1 | Scientific production of rectors of Peruvian universities.

\begin{tabular}{|c|c|c|c|c|c|c|c|c|}
\hline \multirow[t]{2}{*}{ Institution } & \multirow[t]{2}{*}{ Type } & \multirow{2}{*}{$\begin{array}{l}\text { SIR Iberoamérica } \\
2019\end{array}$} & \multicolumn{3}{|c|}{ Publication of articles in indexed journals in } & \multirow{2}{*}{\multicolumn{2}{|c|}{$\begin{array}{l}\text { Index } \mathbf{h} \text { of author Index } \mathrm{h} \text { of author in web } \\
\begin{array}{ll}\text { in Scopus } & \text { of science }\end{array}\end{array}$}} & \multirow[t]{2}{*}{ Renacyt } \\
\hline & & & Scopus & Wos & Total & & & \\
\hline UNIFE & Private & 0 & $\mathrm{Si}$ & $\mathrm{Si}$ & 4 & 1 & 2 & No \\
\hline UPCH & Private & 158 & $\mathrm{Si}$ & $\mathrm{Si}$ & 9 & 5 & 2 & $\mathrm{Si}$ \\
\hline UNI & Public & 390 & $\mathrm{Si}$ & $\mathrm{Si}$ & 10 & 5 & 1 & $\mathrm{Si}$ \\
\hline UP & Private & 454 & $\mathrm{Si}$ & $\mathrm{Si}$ & 3 & 1 & 1 & $\mathrm{Si}$ \\
\hline USAT & Private & 604 & $\mathrm{Si}$ & No & 5 & 5 & 0 & $\mathrm{Si}$ \\
\hline UNTU & Public & 622 & $\mathrm{Si}$ & No & 2 & 2 & 0 & $\mathrm{Si}$ \\
\hline UNSM & Public & 634 & $\mathrm{Si}$ & No & 2 & 2 & 2 & No \\
\hline UTP & Private & 635 & $\mathrm{Si}$ & $\mathrm{Si}$ & 10 & 8 & 0 & $\mathrm{Si}$ \\
\hline
\end{tabular}

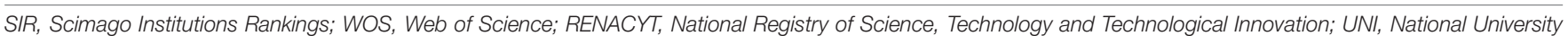

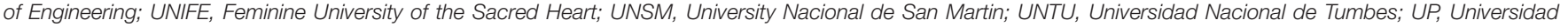

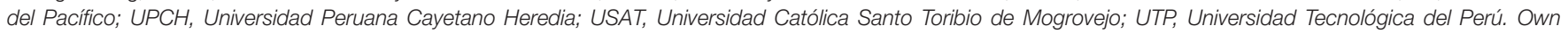
elaboration.

At this point, it is important to remember that universities have as their main function the generation of knowledge through research (Herrera-Añazco et al., 2017). Therefore, the suitability of an authority to occupy a position such as a rector should be reflected by its ability to manage not only the administrative part but also the investigation. That is why, when occupying the main position in a university, and being ultimately responsible for research policies, it is necessary that the position be filled by people with research experience (Herrera-Añazco et al., 2017). In this regard, according to the new Peruvian university law $\left(N^{\circ}\right.$ 30220) (Ministerio de Educacion, 2014), in article 61 the Rector is defined as the representative and legal representative of the university, who is in charge and exclusively dedicated, the direction, conduction and management of the university government in all its areas; According to the same law, the requirements to hold this position include having at least 5 years as a head professor and having the academic degree of doctor. Since that same university law considers research as one of its axes (Mayta-Tristán et al., 2019), it is necessary that the rector as the institution's leader be the first to consider this requirement.

It is here where it is necessary to analyze the profile of the rector, Clark (2017) mentions that among the characteristics that a rector must have are the ability to generate and raise funds and the priority of research as an area of development. For this reason,

TABLE 2 | Percentage distribution of Rectors according to type of publication and its indexing in databases.

\begin{tabular}{|c|c|c|c|c|}
\hline \multirow[t]{2}{*}{ Data base/type of publication } & \multicolumn{2}{|c|}{ Scopus } & \multicolumn{2}{|c|}{ Web of science } \\
\hline & No & $\%(N=45)$ & No & $\%(N=45)$ \\
\hline Original article & 21 & 46.67 & 9 & 20.00 \\
\hline Editorial & 2 & 4.44 & 0 & 0.00 \\
\hline Conference artícle & 7 & 15.56 & 2 & 4.44 \\
\hline Record of meeting & 0 & 0.00 & 2 & 4.44 \\
\hline Erratum & 1 & 2.22 & 0 & 0.00 \\
\hline Obituary & 0 & 0.00 & 1 & 2.22 \\
\hline
\end{tabular}

Own elaboration. we consider that it is important that a rector has in his experience indicators of scientific production, which will facilitate access to funds granted by the National Council of Science and Technology (Espejo, 2016). As seen in the scientific literature, no analysis has yet been made to evaluate the scientific production of the rectors of Peruvian universities. Therefore, in order to clarify if they have capacities for the position to which they were elected, the objective of this research is to identify the scientific production of the rectors of Peruvian universities.

\section{MATERIALS AND METHODS}

Retrospective and descriptive bibliometric study regarding the scientific production published by Peruvian rectors. A nonprobabilistic and intentional sampling was considered. As a unit of analysis, the scientific production of 56 rectors of Peruvian universities (32 private and 24 public), both licensed and in the process of being licensed by the National Superintendency of Higher University Education, was taken into account. The authorities were identified by information provided on their institutional transparency page.

The search for information included 4 moments. First, the names and surnames of the rectors were obtained. Second, a Microsoft Excel file was created in order to record the characteristics of the rectors' publications made between 1998 and 2019, original articles, review articles, scientific letters, letters to the editor, and case studies published in Journals indexed in the Scopus databases, Web of Science. Third, the registered information was corroborated through the combination of surnames and names that were made visible in the ORCID profile, Google Scholar, and the CTI Vitae database (DINA). Fourth, the information obtained was analyzed using the Microsoft Excel program and the SPSS version 25 statistical package. Duplicate articles were not considered in the searches for the analysis.

To carry out this research and taking into account that the manuscripts are available in their respective databases and are in the public domain, the approval of an ethics committee was not necessary. 
TABLE 3 | Percentage distribution of rectors according to level of education, sex and number of publications.

\begin{tabular}{|c|c|c|c|c|c|c|c|c|}
\hline \multirow[t]{4}{*}{ Degree of instruction } & \multicolumn{4}{|c|}{ Male } & \multicolumn{4}{|c|}{ Female } \\
\hline & \multicolumn{2}{|c|}{ With some scientific publication } & \multicolumn{2}{|c|}{ No scientific publication } & \multicolumn{2}{|c|}{ With some scientific publication } & \multicolumn{2}{|c|}{ No scientific publication } \\
\hline & No & $\%$ & No & $\%$ & No & $\%$ & No & $\%$ \\
\hline & & $(n=56)$ & & $(n=56)$ & & $(n=56)$ & & $(n=56)$ \\
\hline Doctor & 5 & 8.93 & 42 & 75 & 3 & 5.36 & 6 & 10.71 \\
\hline
\end{tabular}

Own elaboration.

\section{RESULTS}

Among a total of 56 universities studied, it was found that $14.29 \%$ of Rectors have published articles in scientific journals indexed in Scopus and Web of Science. In addition, it was evidenced that only 7 universities that have a Rector with scientific production appear in the Ibero-American Ranking of Higher Education Institutions (2020 edition), this analyzes indicators related to research, innovation, and the social impact of Ibero-American institutions. The average number of articles published was 5.62 (range 0-10), an indicator that allows comparing and evaluating the relative importance of an article within the same scientific field. On the other hand, the average h-index of each Rector in the Scopus and Web of Science databases is 3.62 and 1.14, respectively. Among the Rectors that have production, only $75 \%$ are registered as researchers in the National Scientific, Technological and Technological Innovation Registry (RENACYT), evaluation and distinctive granted by the National Council of Science and Technology and Technological Innovation (CONCYTEC) institution whose purpose is to regulate, direct, guide, promote, coordinate, supervise, and evaluate the actions of the Peruvian State in the field of Science, Technology (see Table 1).

It is observed that the Rectors' publications are distributed in 6 types of publication sections, of a total of 45 publications, $66.67 \%$ correspond to original articles, while $20 \%$ to conference articles. In addition, $68.89 \%$ of the total refers to publications indexed in Scopus, and a lower percentage with $31.11 \%$ are publications in journals indexed in the Web of Science (see Table 2). Likewise, it is perceived that the areas of knowledge in which it has been published are civil engineering, history, industrial engineering, sociology, life sciences, and human medicine.

The total of Rectors has the degree of Doctor, of which the men have a greater scientific production (5 articles published), represented by $8.93 \%$ of the total, while women represent $5.36 \%$ (see Table 3).

Among the 45 publications, $77.78 \%$ were published in English, while $48.89 \%$ had participated in the role of correspondent authorship a Rector. Finally, 100\% do not declare the financing of an institution within the publication of their article (see Table 4).

Graph 1 describes the history of publications of those people who assume the position of Rector, in the period of time studied. A distribution is made for decades, observing that between 2010 and 2019 there is a notable increase in publications compared to previous decades.

\section{DISCUSSION}

Latin America has had different achievements in relation to its scientific production (Hernández, 2019), led by Brazil, Argentina, Mexico, and Chile (Arteaga-Livias et al., 2020) and despite the low investment compared to developed countries (León et al., 2020). In Peru, the study of scientific production is important and significant growth in scientific production has been observed compared to previous years (Limaymanta et al., 2020). Peruvian universities are in full academic-scientific development, promoted by SUNEDU (Mayta-Tristán et al., 2019) and by the University Law (Ministerio de Educacion, 2014), although only one of them is among the 500 best in global university ranking systems. Scientific activity is essential for university professors (Castro-Rodríguez et al., 2020), especially in a country where a very high percentage of teachers have never published a scientific article (Pereyra-Elías et al., 2014) and that many teachers have published it in a predatory journal, which affects national scientific production (SotomayorBeltran and Zarate Segura, 2021). Therefore, the objective of this research was to identify the scientific production of the rectors of Peruvian universities who play an important role in relation to the development and culture of the institution (Karadag, 2021).

It is also important to mention that scientific production is an indicator of capacities for Peruvian management and evaluation of both undergraduate and graduate programs (SINEACE, 2021). In this sense, it is expected that the first university authority having the degrees of teacher and doctor will have some published

TABLE 4 | Percentage distribution of rector directors according to characteristics of the articles published.

\begin{tabular}{lcc}
\hline Characteristics & No & $\begin{array}{c}\text { \% } \\
\text { ( } \boldsymbol{n}=\mathbf{4 5})\end{array}$ \\
\hline Language & & \\
English & 35 & 77.78 \\
Spanish & 10 & 22.22 \\
Authorship & & \\
Correspondent & 22 & 48.89 \\
Co-author & 23 & 51.11 \\
Financing & & \\
Does not clarify financing & 45 & 100.00 \\
Funded by institution & 0 & 0.00
\end{tabular}


articles. In Latin America and the world, the Scimago ranking is considered for the evaluation of universities, which is based on scientific production at the level of scientific articles (ChinchillaRodríguez et al., 2015; Leon-de La et al., 2018; Ortiz-Núñez, 2020). This study found that the scientific production of the rectors is poor, since of the vast majority of universities, their rectors have not published a single article in WoS or Scopus, this result is similar to other administrative positions (HerreraAñazco et al., 2017; Aquino-Canchari, 2020) and comparable to that of the thesis advisors (Mamani-Benito and FarfánSolís, 2020). Likewise, it was found that the UNI and the UPCH lead the scientific production by the rector. It is also observed that the rector of the Peruvian university best located in the global ranking does not have publications. It is important to note that this result has to take equity aspects into account since it is not entirely fair to compare a large university with a small one because large universities have greater human resources and therefore better groups of researchers (Roman-Gonzalez et al., 2019).

The results found also allow us to highlight that the $\mathrm{H}$ index of the rectors who publish is moderately good, considering that the $\mathrm{H}$ index is a more stable indicator in a specific time (Mayta-Tristán et al., 2019). Likewise, the largest number of articles were original articles and communications in congress, respectively, data similar to others reported in other areas (Sanz-Valero and WandenBerghe, 2017; Moreta and Said-Hung, 2020). Our results also report on gender gaps in the leadership of universities, showing that the majority of rectors are men and that their scientific production is greater than women, data also reported in other studies (Reyes Rodríguez et al., 2019; HernándezGonzález et al., 2020) and different especially in public health areas where women published 1.4 times more than men (Hollmann et al., 2015).

Likewise, the rectors published mostly in English, data that is related to the predominance of this language in different scientific fields and the possibility of receiving higher citations (Sanz-Valero and Wanden-Berghe, 2017; Rodríguez-García et al., 2019a,b), likewise, almost half of the publications were by correspondence authors, which means that this group of rectors leads in their research networks (Mattsson et al., 2011).

Our results also show the impact of the university law, accreditation processes, and financing funds (Roman-Gonzalez et al., 2019), reporting exponential growth in recent years, but that, it is still scarce, similar data were found in relation to the vice-rectors of research (Herrera-Añazco et al., 2017). This result also helps us understand students who perceive in their leaders the lack of capacities to direct them and help them with their research (Mejia et al., 2016; Mamani-Benito et al., 2020) and that it would be important that one of the qualifications to be rector, is related to his qualification by the National Council of Science, Technology and Technological Innovation of Peru (Concytec) and registration as a Renacyt researcher (National Registry of Researchers).

Our results also have some limitations. First, the total number of universities was not included, since only the graduates were considered. Likewise, it is probable that some publications have not been harvested in the databases and therefore were not included, although the journal is indexed in Scopus and WoS. It is also possible that the scientific production of the analyzed rectors has been published in non-indexed journals. Another limitation is that there is no evidence between the scientific production of the rectors and their relationship with university quality, a topic that should be analyzed in a future study. Likewise, it is important that future studies consider the analysis of the scientific production of rectors in other Latin American countries with a greater research tradition. However, the results obtained are important depending on the information taken from the data found on their respective institutional websites.

Considering the evaluation criteria presented by CONCYTEC (2021), where the lowest level is level VII, which considers at least 5 articles published in indexed journals, we consider as a conclusion that the scientific production of the rectors of Peruvian universities is low and presents great heterogeneity and that it is led by the UPCH and the UNI, having the largest number of documents in original format and presenting a significant percentage of authors by correspondence. It is necessary to implement policies that can help universities have better criteria in the election of the rector as the person in charge of institutional growth and its scientific production.

\section{DATA AVAILABILITY STATEMENT}

The original contributions presented in the study are included in the article/supplementary material, further inquiries can be directed to the corresponding author/s.

\section{AUTHOR CONTRIBUTIONS}

JT-C, RC-E, and OM-B conceived and designed the experiments, performed the experiments, analyzed and interpreted the data, and wrote the manuscript. $\mathrm{RH}$ and AA-R contributed reagents, materials, and analysis tools or data, and wrote the manuscript. All authors contributed to the article and approved the submitted version.

\section{SUPPLEMENTARY MATERIAL}

The Supplementary Material for this article can be found online at: https://www.frontiersin.org/articles/10.3389/feduc. 2022.772887/full\#supplementary-material 


\section{REFERENCES}

Aquino-Canchari, C. (2020). Producción científica de los decanos de facultades y directores de escuelas de odontología del Perú. Rev. Cuba. Investig. Biomed. $39,1-7$.

Arteaga-Livias, K., Dámaso-Mata, B., Cornelio, D. K., Lijarza-Ushinahua, K., and Panduro-Correa, V. (2020). Publications in scopus and institutional license status of the medical schools of Peru. Rev. Cuba. Med. Mil. 49: e700.

Castro-Rodríguez, Y., Mendoza-Martiarena, Y., Tello-Espejo, M., and PiscocheRodríguez, C. (2020). Factors associated with the scientific production of academics in the faculty of dentistry of the National University of San Marcos, Lima Perú. J. Oral Res. 8, 471-477. doi: 10.17126/joralres.201 9.069

Chachaima-Mar, J. E., Fernández-Guzmán, D., and Atamari-Anahui, N. (2019). Publicación científica de docentes de una escuela de medicina peruana: frecuencia y características asociadas. Educ. Medica 20, 2-9. doi: 10.1016/j. edumed.2017.10.024

Chinchilla-Rodríguez, Z., Zacca-González, G., Vargas-Quesada, B., and Moya-Anegón, F. (2015). Latin American scientific output in Public Health: combined analysis using bibliometric, socioeconomic and health indicators. Scientometrics 102, 609-628. doi: 10.1007/s11192-0141349-9

Clark, C. (2017). Pathways to the University Presidency. London: Deloitte, 1-32.

CONCYTEC (2021). Reglamento de Calificación, Clasificación y Registro de los Investigacdores del Sistema Nacional de Ciencia. Available online at: https://portal.concytec.gob.pe/index.php/informacion-cti/reglamento-delinvestigador-renacyt (accessed October 15, 2021).

Espejo, K. (2016). Los Beneficios de ser un Investigador Concytec. Publimetro. San Isidro: CONCYTEC.

Glass, R. I., Garcia, P. J., Belter, C. W., Livinski, A. A., and Leon-Velarde, F. (2018). Rapid growth of biomedical research in Peru. Lancet Glob. Health. 6:e728. doi: 10.1016/S2214-109X(18)30234- 1

Hernández, I. (2019). La importancia del impulso a la investigación científica en la Sudamérica emergente. Cirug. Plástica Ibero Latinoam. 45, 207-208. doi: 10.4321/S0376-78922019000200015

Hernández-González, V., De Pano-Rodríguez, A., and Reverter-Masia, J. (2020). Spanish doctoral theses in physical activity and sports sciences and authors scientific publications (LUSTRUM 2013-2017). Scientometrics 122, 661-679. doi: 10.1007/s11192-019-03295-6

Herrera-Añazco, P., Valenzuela-Rodríguez, G., Pacheco-Mendoza, J., and Málaga, G. (2017). Scientific production of Vice chancellors for research in Peruvian universities with a medical school. Medwave 17:e7074. doi: 10.5867/medwave. 2017.08.7074

Hollmann, M., Borrell, C., Garin, O., Fernández, E., and Alonso, J. (2015). Factors influencing publication of scientific articles derived from masters theses in public health. Int. J. Public Health 60, 495-504. doi: 10.1007/s00038-015-0 664-0

Karadag, E. (2021). Academic (dis)qualifications of Turkish rectors: their career paths, H-index, and the number of articles and citations. High. Educ. 81, 301-323. doi: 10.1007/s10734-020-00542-1

León, J., Socorro, A., Librada, C. M., and Pérez, C. (2020). Scientific production in latin america and the caribbean in the period 1996-2019. Rev. Cuba. Med. Mil. $49,1-10$.

Leon-de La, O. D., Thorsteinsdottir, H., and Calderon-Salinas, J. V. (2018). The rise of health biotechnology research in Latin America: A scientometric analysis of health biotechnology production and impact in Argentina, Brazil, Chile, Colombia, Cuba and Mexico. PLoS One 13, 1-28. doi: 10.1371/journal.pone. 0191267

Limaymanta, C. H., Zulueta-rafael, H., Restrepo-arango, C., and Álvarez-muñoz, P. (2020). Análisis bibliométrico y cienciométrico de la producción científica de Perú y Ecuador desde Web of Science (2009-2018). Inf. Cult. Soc. 43, 31-52. doi: 10.34096/ics.i43.7926

Mamani-Benito, O. J., and Farfán-Solís, R. (2020). Publicación científica de asesores de tesis de enfermería de tres universidades del departamento de Puno, Perú. Rev. Cuba. Enferm. 36:e3355.

Mamani-Benito, O., Ventura-León, J., and Caycho-Rodriguez, T. (2019). Publicación cientifica de docentes que conforman el jurado de tesis en una
Facultad de Ciencias de la Salud peruana. Rev. Cuba. Inf. Ciencias Salud 30:e1373.

Mamani-Benito, O., Verastegui-Diaz, A., Mejia, C. R., and Caycho-Rodriguez, T. (2020). Publicación científica de asesores de tesis de psicología de 30 universidades peruanas. Rev. Interam. Psico 54:e1124.

Mattsson, P., Sundberg, C. J., and Laget, P. (2011). Is correspondence reflected in the author position? A bibliometric study of the relation between corresponding author and byline position. Scientometrics 87, 99-105. doi: 10.1007/s11192010-0310-9

Mayta-Tristán, P., Toro-Huamanchumo, C. J., Alhuay-Quispe, J., and PachecoMendoza, J. (2019). Producción científica y licenciamiento de escuelas de medicina en el Perú. Rev. Peru. Med. Exp. Salud Publica 36, 106-115. doi: 10.17843/rpmesp.2019.361.4315

Mejia, C. R., Cáceres, O. J., Vera, C. A., Inga-Berrospi, F., and Mayta-Tristán, P. (2016). Percepción y factores asociados a insatisfacción que los médicos recién graduados tienen de sus asesores de tesis, Lima-Perú. Rev. Cuba. Educ. Medica Super. 30, 340-348.

Mejia, C. R., Valladares-Garrido, M. J., and Valladares-Garrido, D. (2018). Baja publicación en revistas científicas de médicos peruanos con doctorado o maestría: frecuencia y características asociadas. Educ. Méd. 19, 135-141. doi: 10.1016/j.edumed.2017.01.009

Ministerio de Educacion (2014). Ley Universitaria: Ley $N^{\circ}$ 30220. Lima: Diario el Peruano. Available online at: https://www.gob.pe/institucion/minedu/normaslegales/118482-30220

Moquillaza-Alcántara, V. H. (2019). Producción científica asociada al gasto e inversión en investigación en universidades peruanas. An. la Fac. Med. 80, 56-59. doi: 10.15381/anales.v80i1.15626

Moreta, C. D. O., and Said-Hung, E. (2020). La producción científica en el estudio de experiencia de usuario en educación: caso Web of Science y Scopus. Transinformação 32:e190003. doi: 10.1590/2318-0889202032e190003

Ortiz-Núñez, R. (2020). Análisis métrico de la producción científica sobre COVID19 en SCOPUS. Revista Cubana de Informacion en Ciencias de la Salud 31, 1 20. Available online at: http://scielo.sld.cu/scielo.php?script=sci_arttext\&pid= S2307-21132020000300002

Pereyra-Elías, R., Huaccho-Rojas, J. J., Taype-Rondan, Á, Mejia, C. R., and Mayta-Tristán, P. (2014). Publicación y factores asociados en docentes universitarios de investigación científica de escuelas de medicina del Perú. Rev. Peru. Med. Exp. Salud Publica 31, 424-430. doi: 10.17843/rpmesp.2014. 313.76

Reyes Rodríguez, A. D., Olate Pastén, Y., de, L., and Godoy Tapia, C. A. (2019). Análisis bibliométrico de la producción científica de la Revista Actividad Física y Ciencias durante el período 2009-2018. Rev. Ciencias Act. Física 20, 1-25. doi: $10.29035 /$ rcaf.20.2.9

Rodríguez-García, A. M., Raso Sánchez, F., and Ruiz-Palmero, J. (2019a). Competencia digital, educación superior y formación del profesorado: un estudio de meta-análisis en la web of science. Pixel Bit Rev. Medios Educ. 54, 65-82. doi: 10.12795/pixelbit.2019.i54.04

Rodríguez-García, A. M., Trujillo Torres, J. M., and Sánchez Rodríguez, J. (2019b). Impact of scientific productivity on digital competence of future teachers: bibliometric approach on scopus and web of science. Rev. Complut. Educ. 30, 623-646. doi: 10.5209/RCED.58862

Roman-Gonzalez, A., Ciriaco-Susanibar, A., and Vargas-Cuentas, N. I. (2019). Comparing the scientific production of Peruvian universities with equitable indexes. Adv. Sci. Technol. Eng. Syst. J. 4, 394-403. doi: 10.25046/aj04 0448

Sanz-Valero, J., and Wanden-Berghe, C. (2017). Análisis bibliométrico de la producción científica, indizada en MEDLINE, sobre los servicios de salud proporcionados por las unidades de hospitalización a domicilio / Bibliometric analysis of scientific production indexed in MEDLINE, about hospital based. Hosp. Domic. 1, 21-34. doi: 10.22585/hospdomic.vli1.3

SINEACE (2021). Modelo de Calidad Para Acreditación de Programas de Estudio de Educación Superior Universitaria de Posgrado. San Isidro: SINEACE, 1-15.

Sotomayor-Beltran, C., and Zarate Segura, G. W. (2021). Peruvian scientific production affected by predatory journals. Int. Inf. Libr. Rev. 53, 1-7. doi: 10.1080/10572317.2020.1869902

Valenzuela-Rodriguez, G., Herrera-Añazco, P., and Hernandez, A. (2015). Producción científica de los decanos de las facultades de medicina en Perú. Salud Publica Mex. 57, 364-365. 
Valle, R., and Perales, A. (2016). Investigación en salud en el Perú: mucho por hacer y cambiar. Rev. Peru. Med. Exp. Salud Publica 33:833. doi: 10.17843/rpmesp. 2016.334.2576

Conflict of Interest: The authors declare that the research was conducted in the absence of any commercial or financial relationships that could be construed as a potential conflict of interest.

Publisher's Note: All claims expressed in this article are solely those of the authors and do not necessarily represent those of their affiliated organizations, or those of the publisher, the editors and the reviewers. Any product that may be evaluated in this article, or claim that may be made by its manufacturer, is not guaranteed or endorsed by the publisher.

Copyright (ङ 2022 Carranza-Esteban, Turpo-Chaparro, Hernández, Mamani-Benito and Apaza-Romero. This is an open-access article distributed under the terms of the Creative Commons Attribution License (CC BY). The use, distribution or reproduction in other forums is permitted, provided the original author(s) and the copyright owner(s) are credited and that the original publication in this journal is cited, in accordance with accepted academic practice. No use, distribution or reproduction is permitted which does not comply with these terms. 